\title{
The physico-chemical properties and biostimulative activities of humic substances regenerated from lignite
}

\author{
Jan David ${ }^{1 *}$, Daniela Šmejkalová2 ${ }^{2}$ Šárka Hudecová ${ }^{3}$, Oldřich Zmeškal ${ }^{1}$, Ray von Wandruszka ${ }^{4}$, Tomáš Gregor ${ }^{5}$ \\ and Jiří Kučerík ${ }^{*^{*}}$
}

\begin{abstract}
The positive effect of humic acids on the growth of plant roots is well known, however, the mechanisms and role of their physical structure in these processes have not been fully explained yet. In this work, South-Moravian lignite was oxidized by means of nitric acid and hydrogen peroxide to produce a set of regenerated humic acids. The elemental composition, solid state stability and solution characteristics were determined and correlated in vitro with their biological activity. A modified hydroponic method was applied to determine the effects of their potassium salts on Zea mays seedlings roots with respect to the plant weight, root length, root division, and starch and protein content. The relations between the determined parameters were evaluated through Principal Component Analysis and Pearson's correlation coefficients. The results indicated that the most important factor determining the biological activity of South-Moravian lignite potassium humates is related to the nature of self-assemblies, while the chemical composition had no direct connection with the root growth of Zea mays seedlings. It was demonstrated a controlled processing that provided humic substances with different chemical and physicochemical properties and variable biological activity.
\end{abstract}

Keywords: Lignite humic substances; Modification; Thermal analysis; Chromatography; Spectroscopy; Biological activity

\section{Introduction}

Humic substances (humics, HS) are refractory, darkcolored heterogeneous organic compounds produced in the decay of the total biota in the environment (Stevenson 1994). From the chemical point of view, they are a heterogeneous mixture of fragments of lignins, cellulose, suberins and cutins. Their unique structure makes them a versatile material with applications in industry, medicine, environmental protection, and agriculture. It is becoming clearer, that the presence of humics in soil is necessary for sustainable agriculture, due to their ability to condition the soil, enhance its stability and increase its resistance to erosion (Laker et al. 1993;

\footnotetext{
* Correspondence: david@fch.vutbr.cz; kucerik@uni-landau.de ${ }^{1}$ Faculty of Chemistry, Institute of Physical and Applied Chemistry and Materials Research Centre, Brno University of Technology, Purkyňova 464/118, CZ-612 00 Brno, Czech Republic

${ }^{6}$ Institute of Environmental Sciences, Soil and Environmental Chemistry, University of Koblenz-Landau, Fortstrasse 7, D-76829 Landau, Germany Full list of author information is available at the end of the article
}

Spaccini et al. 2002), ensure enhanced biological activity (Canellas et al. 2002; Canellas et al. 2008; Nardi et al. 2000a, b; Zandonadi et al. 2007) and obtain higher crop yields (Antošová et al. 2008; Brownell et al. 1987; Eyheraguibel et al. 2008). In addition, humics have the ability to sequestrate soil pollutants (Evdokimov and von Wandruszka 1998; Sanjay et al. 1999; Senesi and Loffredo 2001; von Wandruszka 2000), and may be used in soil remediation (Fava et al. 2004; Stehlíčková et al. 2009; von Wandruszka 2000).

The biological activity of humics has been recognized in 1917 (Bottomley 1917), while their hormone-like nature was reported later (Canellas et al. 2008; Nardi et al. 2002). Aguirre et al. (2009) noted that the biological activity of humics is based on their ability to promote the expression of selected genes encoding enzymes like $\mathrm{Fe}^{\mathrm{III}}$ chelate reductase, plasma membrane $\mathrm{H}^{+}$ATPase, and $\mathrm{Fe}^{\mathrm{II}}$ high affinity transporter. Mora et al. (2010) questioned this "hormone-like" idea, since no cytokinins, gibberellins and 
indolacetic acid were found in humic acid samples. Instead, they hypothesized that humics enhance the activation of root plasma membrane $\mathrm{H}^{+}$ATPase, since this may cause significant changes in the root-to-shoot distribution of $\mathrm{NO}_{3}^{-}$and therefore of cytokinins and polyamines.

Piccolo et al. (1992) showed that the humic fraction with the highest acid functionality and the smallest molecular size had the greatest effect on plant nitrate uptake and hormone-like activity. In contrast, neither the aliphatic nor the aromatic content of the extracts appeared to play a role in the biological activity (Nardi et al. 2000a, b, and 2002) confirmed those observations and concluded that the smaller molecular size fractions can be partially taken up by the plasmolemma of higher plant cells, whereas the larger fractions (> $3.5 \mathrm{kDa}$ ) interacted only with the cell walls. In contrast, Canellas et al. (2010) showed that the size fractions of vermicompost humics obtained by preparative HPSEC (High performance size exclusion chromatography) had similar biological activities. In the work of Vlčková et al. (2009), the highest biological activity of humics toward Zea mays (tested by the method of Antošová et al. (2008)), was observed for 35-175 kDa molecular weight fraction.

Lignite, i.e. low rank coal, has been recognized as a valuable source of humics (Kučerík et al. 2003). The content of humics can be increased by regeneration processes with nitric acid, potassium manganate (VII), sulfuric acid, or hydrogen peroxide (Berkowitz 1985, Rausa et al. 1994, Kučerík et al. 2003, Vlčková et al. 2009). However, understanding the influence of lignite regeneration on the physicochemical and biological behavior is still incomplete. The same holds true for optimization of the regeneration processes (e.g. regeneration agent, type and concentration, and regeneration time). Since regeneration is most effective in suspension with nitric acid or hydrogen peroxide (Kučerík et al. 2008a, b), the focus of the study is on these two oxidizing agents.

The aims of this work, therefore, are: (i) to elucidate the pertinent processes in South-Moravian lignite treatment; (ii) to test the obtained products from both chemical and physico-chemical perspectives; and (iii) to assess the influence of regeneration on their biological activity in vitro.

\section{Materials and methods}

\section{Lignite regeneration; extraction and preparation of humates}

All the chemicals were obtained from LachNer Ltd., Neratovice, Penta Ltd., Chrudim, (Czech Republic) and SigmaAldrich Co., Steinheim (Germany). South Moravian lignite (kindly provided by Lignit Hodonín Ltd., Mikulčice, Czech Republic) was regenerated with two oxidizing agents - nitric acid (abbreviated as $\mathrm{N}$ ) and hydrogen peroxide (abbreviated as $\mathrm{P}$ ) in concentrations of 10, 20,
$30,40,50,65$ vol\% and $5,10,20,30$ vol\%, respectively. The lignite:oxidizing agent ratio was $1: 10 \mathrm{w} / \mathrm{w}$ (50 g of parental lignite in $500 \mathrm{~mL}$ of regeneration agent). Lignite was treated for 30 minutes at a temperature around $30^{\circ} \mathrm{C}$ in a glass beaker. For the 50 and 65 vol\% nitric acid treatment a round bottom flask with a reflux Allihn condenser and a cooling bath were used, since the regeneration reactions were strongly exothermic. The mixture was filtered and the filtration cake of treated lignite was used for extraction of regenerated humate. A quantity of $40 \mathrm{~g}$ of lignite was subjected to extraction via a slightly modified process published by Swift (1996). It involved an alkaline extraction with a mixture of $0.5 \mathrm{~mol} \mathrm{~L}^{-1}$ sodium hydroxide and $0.1 \mathrm{~mol} \mathrm{~L}^{-1}$ sodium pyrophosphate. The lignite:agent ratio was $1: 10 \mathrm{w} / \mathrm{w}$. Separation was achieved by centrifugation for $15 \mathrm{~min}$ at $15^{\circ} \mathrm{C}$ and $4000 \mathrm{rpm}$ with Rotina $46 \mathrm{R}$ centrifuge (Andreas Hettich Ltd., Tuttingen, Germany), and precipitation by addition of concentrated hydrochloric acid. Further purification included removal of silicate residues with $5 \mathrm{vol} \%$ hydrofluoric acid and dialysis against deionized water through a SpectraPor 1000 Da cutoff dialysis membrane made of regenerated cellulose (Spectrum Labs Inc., Rancho Dominguez, CA, U.S.A.).

After extraction and dialysis, each humic sample was divided into two parts. The first part was freeze dried as such, yielding solid humic acid of low solubility. The second part was titrated with $0.5 \mathrm{~mol} \cdot \mathrm{L}^{-1}$ potassium hydroxide to a $\mathrm{pH}$ of 7.2, using a TitroLine Alpha Plus automated titrator (Schott Inc., Mainz, Germany), and then freeze dried. This yielded water soluble potassium humate. Freeze drying was carried out with Freezone 4.5 freeze dryer at $-50^{\circ} \mathrm{C}$ and $120-140 \mathrm{mPa}$ (Labconco Corp., Kansas City, MO, U.S.A.). The products obtained were crushed in an agate mortar, weighed, and stored in sealed vials in a dry, dark location. The samples descriptions are summarized in Table 1.

\section{Solid state analyses of humic acids Elemental analysis}

Elemental analyses of HA and RHA samples were conducted employing a Perkin Elmer 2400 CHNS/O Elemental Analyzer. The oxygen percentage was calculated as a difference between the sample weight and the $\mathrm{C}, \mathrm{H}$, and $\mathrm{N}$ content, taking into account the moisture and ash contents determined by thermogravimetry (see below).

\section{Thermogravimetry}

The influence of regeneration on the thermooxidative stability of humics products was assessed by thermogravimetry. Prior to the analysis, the samples were dried for two weeks over sodium hydroxide, and then analyzed with a Q5000 IR TGA instrument (TA Instruments Inc., New Castle, DE, U.S.A.). The $100-\mu \mathrm{L}$ platinum pans of 
Table 1 Sample descriptions

\begin{tabular}{|c|c|}
\hline $\begin{array}{l}\text { Sample } \\
\text { abbreviation }\end{array}$ & Sample description \\
\hline $\mathrm{HA}$ & Humic acid from parental lignite. \\
\hline RHA10N-RHA65N & $\begin{array}{l}\text { Humic acid from lignite regenerated with } \\
\text { nitric acid solution }(\mathrm{N}) \text {, the number means } \\
\text { vol\% concentration. }\end{array}$ \\
\hline RHA5P-RHA30P & $\begin{array}{l}\text { Humic acid from lignite regenerated with } \\
\text { hydrogen peroxide }(P) \text { solution, the number } \\
\text { means vol\% concentration. }\end{array}$ \\
\hline $\mathrm{KHA}$ & Potassium humate salt from parental lignite. \\
\hline KRHA10N-KRHA65N & $\begin{array}{l}\text { Potassium humate salt from lignite regenerated } \\
\text { with nitric acid solution }(\mathrm{N}) \text {, the number means } \\
\text { vol\% concentration. }\end{array}$ \\
\hline KRHA10N-KRHA65N & $\begin{array}{l}\text { Potassium humate salt from lignite regenerated } \\
\text { with hydrogen peroxide }(P) \text { solution, the number } \\
\text { means vol\% concentration. }\end{array}$ \\
\hline
\end{tabular}

the apparatus were used as sample holders, and the analysis was carried out using a $10^{\circ} \mathrm{C} \cdot \mathrm{min}^{-1}$ temperature ramp from room temperature (RT) to $650^{\circ} \mathrm{C}$, under a $50 \mathrm{~mL} \cdot \mathrm{min}^{-1}$ flux of dry air.

\section{Fourier transform infrared spectrometry}

Infrared spectra were obtained using potassium bromide pellets technique, in which $1 \mathrm{mg}$ of oven dried $\left(105^{\circ} \mathrm{C}, 3 \mathrm{~h}\right)$ humic material (HA and RHA) was mixed with $200 \mathrm{mg}$ of dried FTIR grade $\mathrm{KBr}$. Spectra were measured with a Thermo Nicolet iS10 infrared spectrometer (Thermo Fisher Scientific Inc., Waltham, MA, U.S.A.). The instrument was set up with a resolution of $8 \mathrm{~cm}^{-1}$ and 64 scans per analysis. The spectra were processed using the Nicolet Omnic 8 software.

\section{Liquid state analyses of humates Dynamic light scattering}

Dynamic light scattering measurements were obtained with a N4 Plus Submicron Particle Sizer equipped with $\mathrm{He}-\mathrm{Ne}$ red laser of wavelength of $632.8 \mathrm{~nm}$ (Coulter Corp., Miami, FL, U.S.A.), calibrated using latex beads from the producer. Sample solutions of $250 \mathrm{mg} \cdot \mathrm{L}^{-1}$ were prepared in water and filtered through GN $0.2 \mu \mathrm{m}$ filters (Millipore Corp., Billerica, MA). Unimodal Analysis Mode was used with a detection angle of $90^{\circ}$. Measurements were taken in 10 runs of $300 \mathrm{~s}$ each, at $25^{\circ} \mathrm{C}$ in a 1 -cm quartz cuvette. Outlying values were excluded according to the Dean-Dixon test (Dean and Dixon 1951).

\section{High performance size exclusion chromatography}

High performance size exclusion chromatography (HPSEC) experiments were performed using an Ultimate 3000 Standard Chromatography Station (Dionex Inc., Sunnyvale, CA, U.S.A.), equipped with a BioSep S2000 $600 \times 7.8 \mathrm{~mm}$ column, and a BioSep Guard pre-column with a $0.2-\mu \mathrm{m}$ stainless steel inlet filter (Phenomenex Inc., Torrance, CA, U.S.A.). The column was thermostated at $25^{\circ} \mathrm{C}$, and a diode array detector was employed. The eluent was a $50 \mathrm{mmol} \cdot \mathrm{L}^{-1}$ solution of $\mathrm{NaH}_{2} \mathrm{PO}_{4} \cdot \mathrm{H}_{2} \mathrm{O}$ in MilliQ water adjusted to $\mathrm{pH} 7$ by means of $1 \mathrm{M} \mathrm{NaOH}$ solution. The flow rate was set at $0.6 \mathrm{~mL} \cdot \mathrm{min}^{-1}$. Samples were prepared as $0.6 \mathrm{mg} \cdot \mathrm{mL}^{-1}$ solutions of potassium humate dissolved in mobile phase, and $100 \mu \mathrm{L}$ of the sample was injected. The calibration of the column was performed using poly(styrenesulphonate) standards of 194.2, 145, 32.9, 14.9, 6.53 and $0.91 \mathrm{kDa}$ mass (Polymer Standards Service Ltd., Mainz, Germany). Calibration curves and results were obtained using Dionex Chromeleon, Microsoft Excel, and OriginLab software. The weight averaged $\left(M_{\mathrm{W}}\right)$ and number averaged $\left(M_{\mathrm{N}}\right)$ molecular weights of the humates were calculated according to the Mori and Barth (1999). For the purpose of comparison, an 1100 Series Chromatography Station (Agilent Inc., Santa Clara, CA, U.S.A.) equipped with quaternary pump and an RI detector was used with the same column and under identical conditions. Calibration was carried out using polysaccharide standards (of 404, 212, 112, 47.3, 5.9, $0.667 \mathrm{kDa}$ mass, same purveyor).

\section{Humate hydration}

In order to determine the amount of water of hydration bound by the humics, a high resolution ultrasonic spectrometer (HRUS 102, Sonas Technologies Ltd., Dublin, Ireland) was employed. Measurements of ultrasonic velocity for each sample were conducted in two independent quartz cells, stirred at $600 \mathrm{rpm}$ with bottom and top stirrers. The system was kept at $25.00 \pm 0.02^{\circ} \mathrm{C}$, using a water bath. The instrument was calibrated with deionized water at $25.00 \pm 0.02^{\circ} \mathrm{C}$. Ultrasonic experiments are based on the determination of difference in ultrasonic velocities in cell 1 ( $1 \mathrm{~mL}$ of sample solution) and cell 2 ( $1 \mathrm{~mL}$ of pure water) (the U12 value). The concentration of the sample (potassium humate) was always $250 \mathrm{mg} \cdot \mathrm{L}^{-1}$, measurements of ultrasonic velocity were repeated three times at three different frequencies $(5478,7850$ and $12196 \mathrm{kHz})$.

High resolution density measurements were performed for the same solutions, in triplicates, with a DMA 4500 density meter (Anton Paar Ltd., Graz, Austria).

Resulting compressibility $(\beta)$ and hydration of the humates were calculated according to equations published by Davies et al. (1982), which assumes that the compressibility of hydration water is much lower than that of non-interacting solvent and of the humic substances themselves.

\section{Biological activity}

The common maize Zea mays CEKLAD 235 species (Oseva Bzenec Ltd., Czech Republic) was selected in the 
biological studies as treated seed for its universality, easy availability, high durability, and good germination percentage. The seeds were treated for $5 \mathrm{~min}$ in a $50 \mathrm{mM}$ sodium hypochlorite $(\mathrm{NaClO})$ solution and then washed and immersed in deionized water for $4 \mathrm{~h}$ to precondition them for germination. The germination was conducted in wet Tork Wiper 430 paper laboratory towels (Thermo Fisher Scientific Ltd., Pardubice, Czech Republic), into which the seeds were rolled, separated by approximately $3 \mathrm{~cm}$ gaps. The paper rolls with seeds were put in a glass beaker containing deionized water and left to germinate for 2 days in the dark at $28 \pm 2^{\circ} \mathrm{C}$, employing a BT- 120 Biological Thermostat (Laboratorní prístroje Praha Ltd., Prague, Czech Republic).

Selected germs $(2-4 \mathrm{~cm})$ were planted in polystyrene containers, with 30 germs per container and each placed in a marked position on a floating styrofoam bed to allow the observation of root length and division (see Figure 1). A solution of $2 \mathrm{mM} \mathrm{CaCl}_{2}$, without nutrients added, was employed as a control (Zandonadi et al. 2007). The humate sample solutions (1 L per vessel) contained $2 \mathrm{mM} \mathrm{CaCl}$ and $40 \mathrm{mg} \cdot \mathrm{L}^{-1}$ potassium humate (Antošová et al. 2008). For the purpose of comparison, a commercial nitrophenolate growth promoter (AtonikPro, ArystaLifeScience, Czech Republic) was also included in the testing regimen. This solution contained $0.4 \mathrm{vol} \%$ of the product (manufacturer's recommendation) and $2 \mathrm{mmol} \cdot \mathrm{L}^{-1}$ solution of $\mathrm{CaCl}_{2}$. A combination solution containing $1 \mathrm{~L}$ of $2 \mathrm{mM} \mathrm{CaCl}_{2}, 0.4 \mathrm{vol} \%$ of AtonikPro, and $40 \mathrm{mg} \cdot \mathrm{L}^{-1}$ of KRHA10N (potassium humate from lignite regenerated with $10 \mathrm{vol} \% \mathrm{HNO}_{3}$ ) humate was prepared too, as well as a similar solution with KRHA30P (potassium humate from lignite regenerated with $30 \mathrm{vol} \%$ $\mathrm{H}_{2} \mathrm{O}_{2}$ ). The growth experiments were conducted in a BT 120 device for 5 days at $25 \pm 2^{\circ} \mathrm{C}$. A cycle of twelve hours of simulated daylight per day was produced with a NanoLight $9 \mathrm{~W}$ lamp of 600 lumen (Dennerle Ltd., Vinningen, Germany), placed $20-30 \mathrm{~cm}$ from the plants. This resulted in a light intensity of 1500-2500 lux. Remaining $12 \mathrm{~h}$ of the experiment proceeded in the dark. All the containers were continually aerated by means of a Precision Aquarium Pump of $4 \mathrm{~W}$ power and $275 \mathrm{~L} \cdot \mathrm{h}^{-1}$ flow rate (Sera Ltd., Hainsberg, Germany). All the experiments were performed in duplicate. Germination tests were not performed, since they have been already studied for the humic acid extracted from South-Moravian lignite by Šerá and Novák (2011), when germination stimulating effects have been proven for this humic acid even on non-cultural plant of Lamb's Quarters (Chenopodium album). Similarly, the stress tests on the plants have not been applied, since the plants seemed to present uniform leave numbers, lengths and areas and these would be far beyond the scope of this work.

\section{Biological activity assessment}

The germinated seeds and grown plants were weighed and the differences were recorded in terms of total mass increment. In addition, the lengths of the roots of five marked germs/plants were measured before and after the growing experiment, and the differences in root

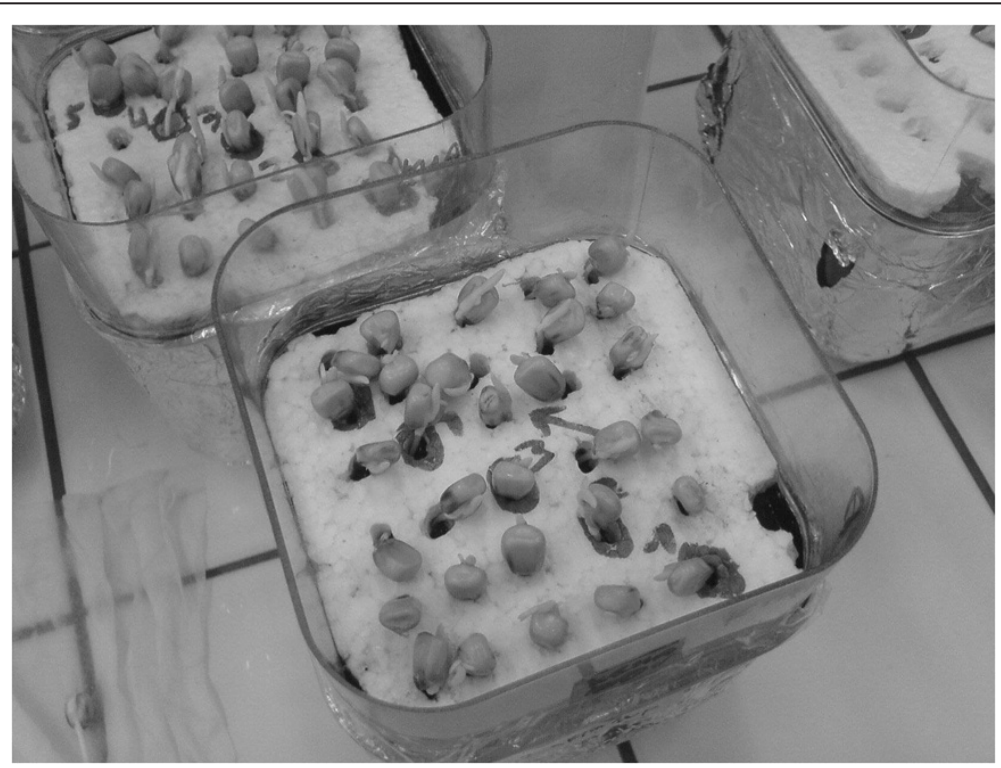

Figure 1 Placing the germs in testing polystyrene containers, with 30 germs per container and each 5 of them placed in a marked position on a floating styrofoam bed to be observed later for root length and division. 
growth were recorded. The roots of these five plants were also scanned with a Perfection 2480 Photo Scanner (Epson Deutschland Ltd., Meersbuch, Germany) against a black background. The resulting images $(300 \times 300$ dpi) were captured by means of HarFA (Harmonic and Fractal image Analyzer) software (http://www.fch.vutbr. cz/lectures/imagesci) (Zmeškal et al. 2001), which was previously shown to be suitable for the evaluation of images from biological experiments (Tománková et al. 2006) and neuroscience (Wu et al. 2010). The scanned images were saved as bitmaps and subjected to 2D Wavelet Analysis. Overall results of biological activity were assessed by means of R Environment for Statistical Computing software (http://www.R-project.org) (R Development Core Team 2012). The root growth increments for the particular 15 samples were statistically compared using a one-way analysis of variance (ANOVA). Post-hoc multiple comparisons were conducted using Tukey's HSD (Honestly Significant Difference) test. The assumptions were evaluated using Levene's test and the Shapiro-Wilk's test. Slight discrepancies vis-à-vis the normality assumptions were disregarded, as they were considered to have minimal impact on the results.

Rather than plants stress tests, we focused on the determination of sugars and protein in the seedlings. After the image analysis, the seedlings were dried in a laboratory dryer for three days at $60^{\circ} \mathrm{C}$. The total dry mass was divided for determination of sugars and proteins. The sugar content was determined polarimetrically using the customary Ewers polarimetric method (Kennedy et al. 1995). The proteins were determined by the Kjeldahl method (McClements 2001) for the determination of total nitrogen. An automatic Kjeldahl analyzer Kjel-Tec ${ }^{\mathrm{Tm}}$ 2100 (FOSS Inc., Hillerød, Denmark) was used.

\section{Results and discussion}

\section{Lignite treatment and humate regeneration}

Table 2 shows the yields of humate regenerated from lignite. Regeneration resulted in higher yields, when performed with nitric acid, with the exception of $10 \mathrm{vol} \%$ $\mathrm{HNO}_{3}$. Regarding the hydrogen peroxide treated lignites, only the 20P sample gave a greater HA yield than direct extraction from parental lignite.

\section{Solid state analyses of humic acids}

Results of the elemental analysis are presented in Table 2. A notable feature of the lignite treatment was the variation in nitrogen content of the regenerated humic acids - especially through treatment with $20-40$ vol\% $\mathrm{HNO}_{3}$. The increase in nitrogen content in samples RHA20N to RHA40N, and the slight decrease in RHA50N and RHA65N confirmed the previous observation about the concentration effect on the yield (Kučerík et al. 2003). The $\mathrm{HNO}_{3}$ treatment resulted in producing of nitrogen enriched humic substances, with the exception RHA10N. This is in contrast to the results reported previously by Čtvrtníčková et al. (2011) and Vlčková et al. (2009) who reported an $\mathrm{N}$ increase in the regenerated products obtained in a similar process. The reason for this discrepancy is not entirely clear; it might be related to variation of humics from batch to batch within the same source. The $\mathrm{HNO}_{3}$ treated samples showed also a higher oxygen content and larger $\mathrm{O} / \mathrm{C}$ ratio, indicating an increase in the number of oxygen bearing groups. Comparison with humic standards provided by International Humic Substances Society (IHSS 2013) shows that the samples from the nitric acid treated lignite were, in terms of N content, more reminiscent of Elliot Soil HA than of Leonardite HA. HA obtained from $\mathrm{H}_{2} \mathrm{O}_{2}$ treated lignite had lower oxygen content and $\mathrm{O} / \mathrm{C}$ ratio, higher $\mathrm{H}$ content and $\mathrm{H} / \mathrm{C}$ ratio and lower $\mathrm{N}$ content. Since the $\mathrm{O}$ content was calculated as a difference, the determined value may include traces of $S$ and $P$.

The regenerated humic acids were characterized by thermogravimetry and results were compared with humics extracted from parental lignite (parental HA). Selected thermo-oxidative curves are shown in Figure 2. These decomposition curves were comparable to results obtained by other groups and they were typical for lignitic humic substances (Gonet and Cieslewicz 1998). The parameters extracted from TGA curves are summarized in Table 2. It is worth to mention that the onset temperatures represent a measure of the thermooxidative stability. The rate of material degradation is clear from the DTG curves in Figure 2. The first peak of the DTG curve $\left(150-350^{\circ} \mathrm{C}\right)$, which is generally ascribed to the degradation of the labile part of humics, was steeper and associated with larger mass loss in the RHA samples, while the second, higher and narrower DTG peak $\left(450-550^{\circ} \mathrm{C}\right.$, assigned to stable structures) was generally lower. The lower onset temperatures and steeper degradation curves of regenerated HA samples indicate a relative enhancement of aliphatic structures and polar functionalities, which are generally less thermo-oxidative stable than aromatic moieties (Plante et al. 2009). These findings are in agreement with negative correlations between the $\mathrm{H} / \mathrm{C}$ and $\mathrm{N} / \mathrm{C}$ ratios and the thermal stability reported by Gonet and Cieslewicz (1998).

FTIR spectra of all HA and RHA materials were comparable to those reported in the literature (Stevenson 1994), examples are reported in Figure 2. The incorporating of nitrogen atoms into the humic structure by the $\mathrm{HNO}_{3}$ lignite treatment was confirmed by $1540-1520 \mathrm{~cm}^{-1}$ peaks due to the $\mathrm{Ar}-\mathrm{NH} / \mathrm{NO}_{2}$ moiety (RHA20N-RHA65N samples). The strong effect of concentrated $\mathrm{HNO}_{3}$ was corroborated by the $1333 \mathrm{~cm}^{-1}$ peak of CO-NH and $\mathrm{NO}_{2}$ (in RHA40NRHA65N samples). In the RHA20P and RHA30P samples, the $1269 \mathrm{~cm}^{-1}$ peak of aromatic/R-COOR moieties was 
Table 2 Results of solid humic acids analyses

\begin{tabular}{|c|c|c|c|c|c|c|c|c|c|c|c|c|c|c|c|}
\hline \multirow{2}{*}{ Sample } & & \multirow{2}{*}{$\begin{array}{l}\text { Yield } \\
\text { [wt\%] }\end{array}$} & \multicolumn{7}{|c|}{ Elemental analysis } & \multicolumn{3}{|c|}{ Thermogravimetry } & \multicolumn{3}{|c|}{ FTIR Relative peak intensity ratios } \\
\hline & & & C & $\mathrm{H}$ & $\mathrm{N}$ & 0 & $\mathrm{H} / \mathrm{C}$ & $\mathrm{N} / \mathrm{C}$ & $\bar{O} \mathrm{O} / \mathrm{C}$ & Humidity & 1st onset & $\overline{\text { Ash }}$ & Aliph./Arom. & Arom./O- groups & Arom./Amid. \\
\hline \multirow{11}{*}{ RHA samples } & & 10.7 & 43.5 & 37.0 & 0.9 & 18.6 & 0.85 & 0.02 & 0.43 & 5.8 & 202.8 & 0.9 & 1.24 & 0.93 & 108 \\
\hline & $10 \mathrm{~N}$ & 11.0 & 40.0 & 45.8 & 0.6 & 13.6 & 1.15 & 0.02 & 0.34 & 5.4 & 226.6 & 0.5 & 1.23 & 0.99 & 1.08 \\
\hline & $20 \mathrm{~N}$ & 28.4 & 38.2 & 42.7 & 2.1 & 16.9 & 1.12 & 0.06 & 0.44 & 5.8 & 134.8 & 0.3 & 1.20 & 0.96 & 0.98 \\
\hline & $30 \mathrm{~N}$ & 24.6 & 37.9 & 42.0 & 2.4 & 17.7 & 1.11 & 0.06 & 0.47 & 5.8 & 162.4 & 0.4 & 1.24 & 0.96 & 0.95 \\
\hline & $40 \mathrm{~N}$ & 18.8 & 38.3 & 40.9 & 2.9 & 17.8 & 1.07 & 0.08 & 0.46 & 4.3 & 153.1 & 0.4 & 1.13 & 0.97 & 0.94 \\
\hline & $50 \mathrm{~N}$ & 34.7 & 38.4 & 41.1 & 2.7 & 17.8 & 1.07 & 0.07 & 0.46 & 4.9 & 152.6 & 0.5 & 1.20 & 0.97 & 0.93 \\
\hline & $65 \mathrm{~N}$ & 35.5 & 36.7 & 43.5 & 2.9 & 17.0 & 1.19 & 0.08 & 0.46 & 5.2 & 169.7 & 0.5 & 1.18 & 0.98 & 0.90 \\
\hline & $5 P$ & 10.1 & 41.6 & 43.4 & 0.9 & 14.1 & 1.04 & 0.02 & 0.34 & 6.2 & 200.1 & 0.3 & 1.22 & 0.98 & 1.18 \\
\hline & $10 P$ & 9.1 & 40.2 & 44.5 & 0.8 & 14.5 & 1.11 & 0.02 & 0.36 & 6.2 & 192.2 & 0.3 & 1.25 & 0.98 & 1.12 \\
\hline & $20 P$ & 13.6 & 39.2 & 45.1 & 0.7 & 15.0 & 1.15 & 0.02 & 0.38 & 4.7 & 169.8 & 0.3 & 1.31 & 0.98 & 1.14 \\
\hline & $30 P$ & 7.0 & 38.9 & 46.6 & 0.4 & 14.1 & 1.20 & 0.01 & 0.36 & 3.7 & 204.0 & 0.3 & 1.24 & 0.99 & 1.07 \\
\hline
\end{tabular}



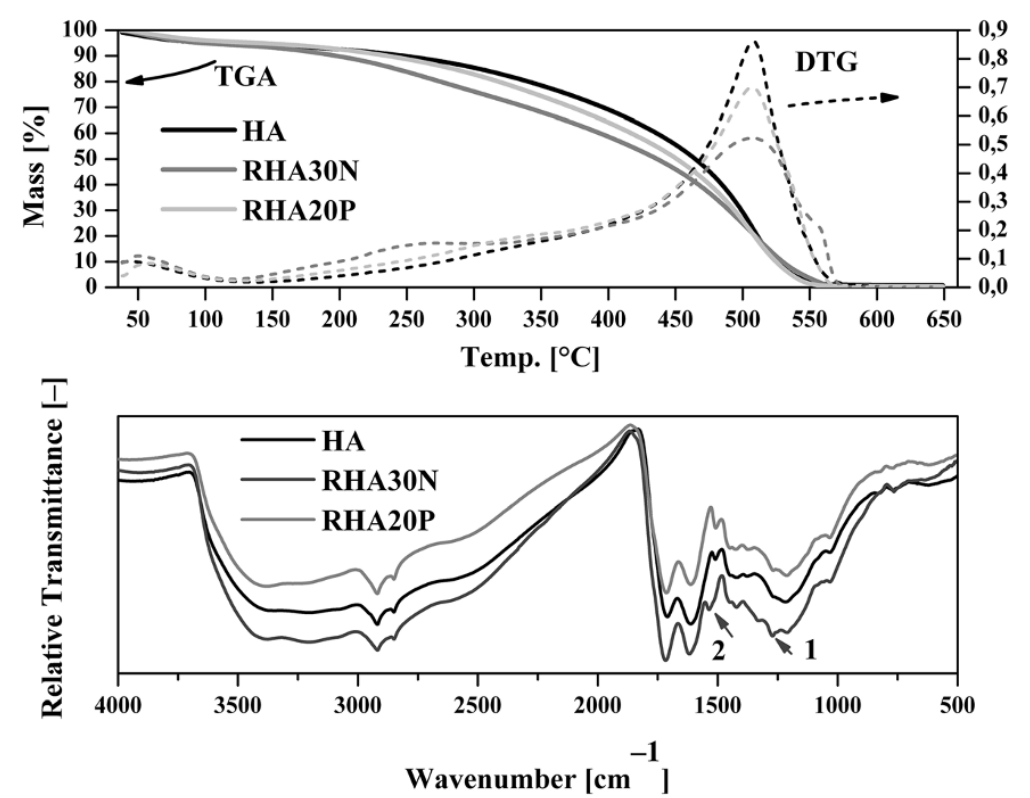

Figure 2 Thermogravimetrical (TGA) curves (line - TGA, dashed - DTG [1st TGA derivative]) and Fourier transform infrared (FTIR) spectra of selected solid samples (HA - black, RHA30N - grey, RHA20P - light grey).

also present. To distinguish between parental HA and the RHA samples, we calculated the intensity ratio of the 2930 and $1610 \mathrm{~cm}^{-1}$ absorption bands (i.e. aliphatic/aromatic ratio) (Table 2). To assess the lignite modification by $\mathrm{HNO}_{3}$, we determined also the intensity ratios of the absorption bands at $1550-1520 \mathrm{~cm}^{-1}$ (amidic) and $1610 \mathrm{~cm}^{-1}$ (aromatic). All the regenerated samples gave a slightly higher aliphatic/aromatic ratio than parental HA. The highest value was obtained for RHA40N, followed by the samples RHA65N, RHA50N, RHA20N and RHA5P. The lowest aliphatic content (but still higher than the HA sample) appeared in the RHA30P sample.

\section{Liquid state analyses}

Dynamic light scattering measurements (DLS) showed the presence of large dimension particles, most likely aggregates of diameters varied in the range 100-500 nm (Figure 3). In view of the pseudomicellar model of humic aggregation and when compared to the DLS results of Palmer and von Wandruszka (2001), the humate samples showed abnormal behavior. The KHA, KRHA20N, KRHA30N and KRHA65N samples had an aggregate size of $275-325 \mathrm{~nm}$ at $25^{\circ} \mathrm{C}$ (Figure 3) which is comparable to previously found values, for the Leonardite humic acid and Nordic aquatic IHSS humics (Palmer and von Wandruszka 2001). On the other hand, KRHA50N, KRHA5P and KRHA30P samples had smaller aggregate sizes of 125-175 nm, comparable to Summit Hill humic acid and Suwannee River humic acid. From this perspective, the regeneration brought more soil-humic-acid-like behavior to the samples. The fluctuation of the aggregate sizes with increasing temperature can be ascribed to the amphiphilic nature of humic acids and the reduction of their hydration sphere (Drastík et al. 2013).

High performance size exclusion chromatography (HPSEC) experiments were conducted with refractive index detector (RID) and diode array detector (DAD) in order to avoid the underestimation of a variety of molecular fractions absorbing in the visible range. All measurements produced a bimodal distribution (Figures 4 and 5). The sharp peak with a retention time (RT) of 18 min was attributed to the total exclusion of the largest solute components (aggregates or chain segments, composed mainly of hydrophobic alkyl chains with no fluorescence or UV absorption). Smaller species were eluted subsequently giving a peak between 20 and $45 \mathrm{~min}$, ascribed to the shorter conjugated alkenes and strongly fluorescing or UV absorbing aromatics (Conte et al. 2007, von Wandruszka et al. 1999). HPSEC utilizing RID gave similar results for all samples, with only slight differences in RT and overall peak shape. The great differences were found between potassium humates obtained from parental and treated lignites, the $\mathrm{HNO}_{3}$ treatment of lignite caused an increased unsaturated content in the humates. The KRHA40N and KRHA65N samples showed fewer long chains, while the samples obtained from peroxidized lignite contained a significantly higher proportion of this fraction. The DAD showed a decrease in humate absorbance with the increasing wavelength (Figure 5), while the combined DAD peak area at a particular retention time and wavelength reflected the content of specific humic components. 

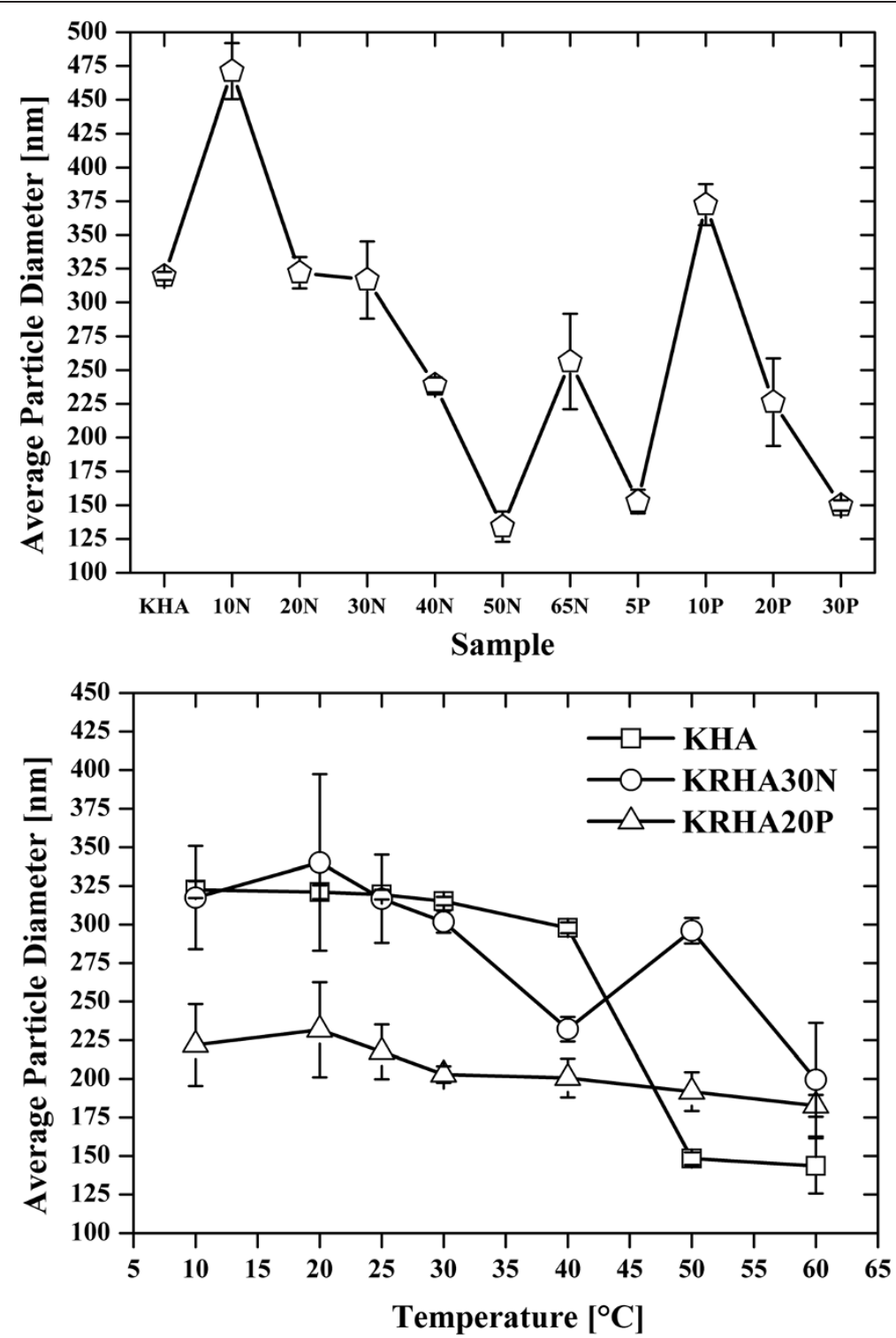

Figure 3 Dynamic light scattering (DLS) results of humate solutions, temperature variability of aggregate size (up; pentagons), aggregate sizes for different samples at $25^{\circ} \mathrm{C}$ (down; squares - KHA, circles - KRHA30N, triangles - KRHA20P).

The peak areas were plotted against the respective wavelengths, emphasizing the differences between investigated samples (Figures 4 and 5). The regeneration, except for KRHA40N, increased the chromophoric content of the humic matter. This indicates that the oxidation of lignite had a major impact on the aliphatic moieties, while affecting the aromatic ones to a lesser extent. The irregular behavior of KRHA40N was probably due to inhomogeneities in the lignite fraction used in the preparation of this sample. The observed differences between $M_{\mathrm{W}}$ and $M_{\mathrm{N}}$ among the humate samples (Table 3) indicated a high degree of polydispersity and potentially chemical heterogeneity in the materials. The RID results indicate that nitric acid treatment decreased the molecular mass of extracted humic acids, while peroxide had the opposite effect. The $M_{\mathrm{W}} / M_{\mathrm{N}}$ ratio was used as an indicator of the system polydispersity (PDI), and results showed that higher concentrations of oxidizing agent caused a narrower mass distribution while lower concentration caused a slight increase (RID). This was in line with recent results indicating that the oxidation of lignite proceeds in several steps depending on the oxidation time and/or strength of oxidizing agent (Kučerík et al. 2008a, b). The integrated DAD spectral peak areas, after division into 6 intervals of mass distribution, clearly showed the differences between the samples (Figure 5).

The hydration of humates was studied by means of high resolution ultrasonic velocimetry and density 


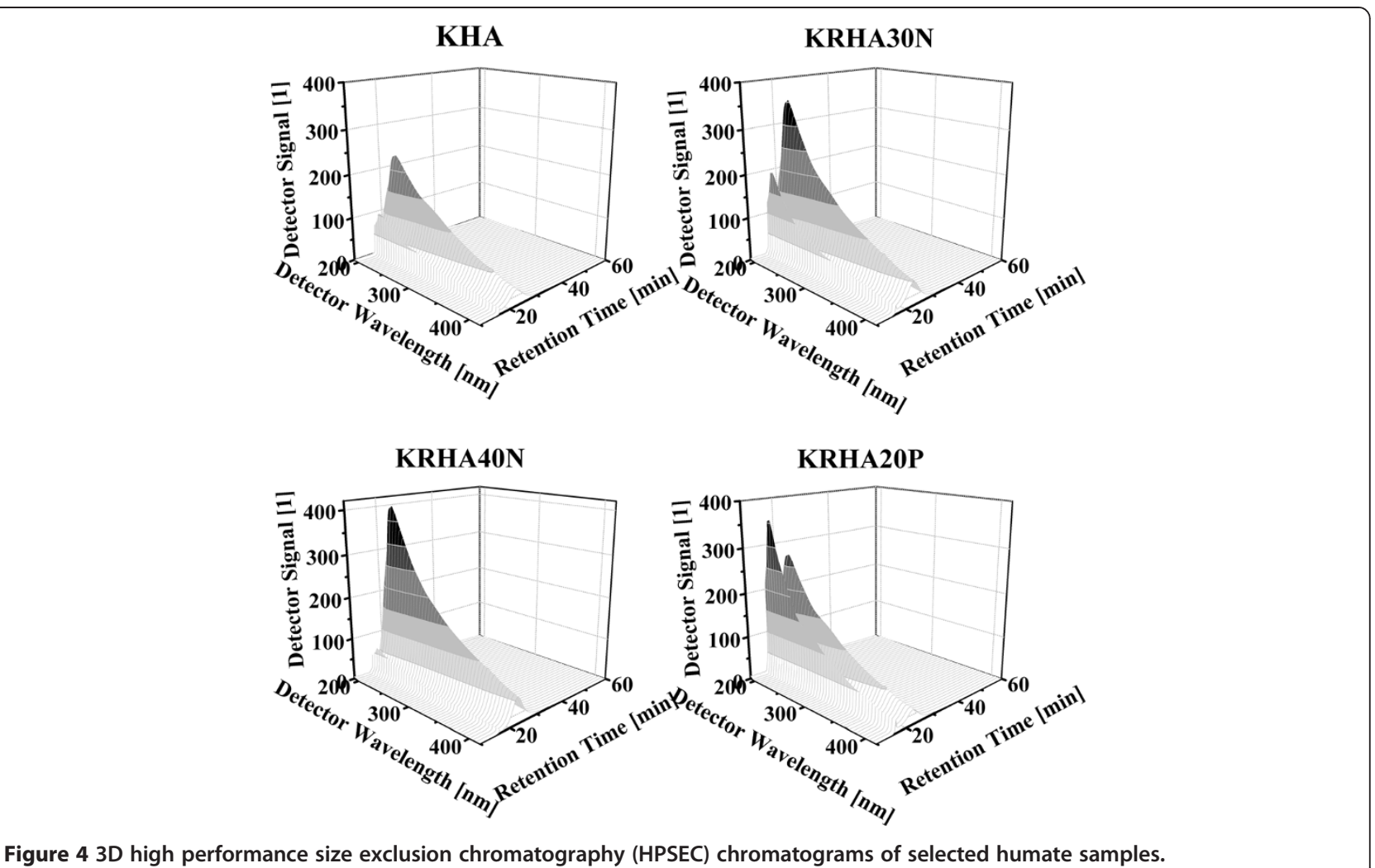

Figure 4 3D high performance size exclusion chromatography (HPSEC) chromatograms of selected humate samples.
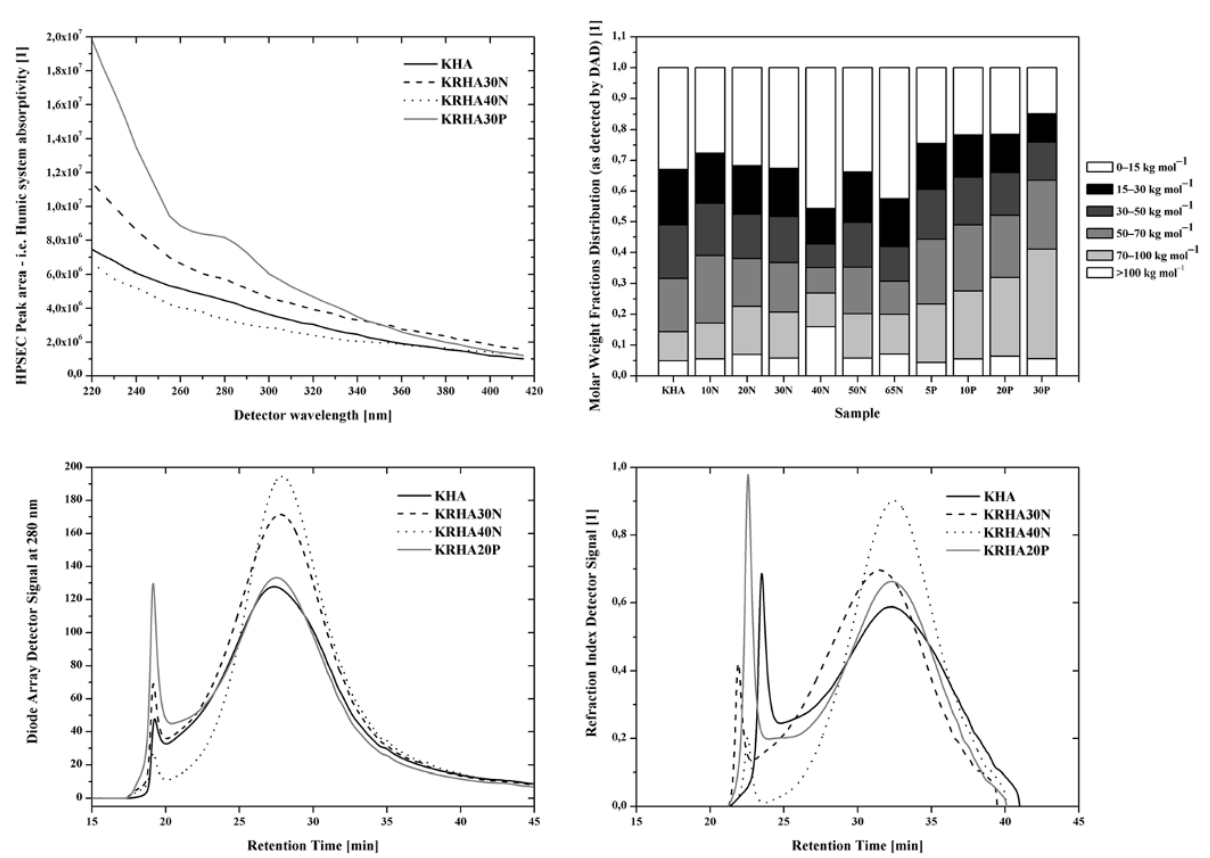

Figure 5 High performance size exclusion chromatography with Diode array detection (HPSEC DAD) peak area of selected humate samples (upper left; line - KHA, dash - KRHA30N, dot - KRHA40N, grey - KRHA30P), molar weight distribution as detected by DAD at $280 \mathrm{~nm}$ in humate samples (upper right; greyshades according to the legend), DAD detector signal at $280 \mathrm{~nm}$ (lower left) and RID signal (lower right; for both the lower charts: line - KHA, dash - KRHA30N, dot - KRHA40N, grey - KRHA20P). 
Table 3 Results of high performance size exclusion chromatography as detected by DAD and RID

\begin{tabular}{|c|c|c|c|c|c|c|c|}
\hline \multicolumn{2}{|c|}{ Sample } & $\begin{array}{c}M_{\mathrm{N}}(280 \mathrm{~nm} \text { DAD }) \\
{\left[\mathrm{g} \cdot \mathrm{mol}^{-1}\right]}\end{array}$ & $\begin{array}{c}M_{\mathrm{W}}(280 \mathrm{~nm} \text { DAD }) \\
{\left[\mathrm{g} \cdot \mathrm{mol}^{-1}\right]}\end{array}$ & $\begin{array}{c}\text { PDI } \\
(280 \mathrm{~nm} \text { DAD) [1] }\end{array}$ & $\begin{array}{l}M_{\mathrm{N}}(\mathrm{RID}) \\
{\left[\mathrm{g} \cdot \mathrm{mol}^{-1}\right]}\end{array}$ & $\begin{array}{l}M_{\mathrm{W}}(\mathrm{RID}) \\
{\left[\mathrm{g} \cdot \mathrm{mol}^{-1}\right]}\end{array}$ & $\begin{array}{c}\text { PDI } \\
\text { (RID) [1] }\end{array}$ \\
\hline \multirow{11}{*}{ KRHA samples } & $\mathrm{KHA}$ & 7879 & 89733 & 11.39 & 6716 & 52915 & 7.88 \\
\hline & $10 \mathrm{~N}$ & 8954 & 107105 & 11.96 & 6474 & 52180 & 8.06 \\
\hline & $20 \mathrm{~N}$ & 8715 & 91669 & 10.52 & 5805 & 36275 & 6.25 \\
\hline & $30 \mathrm{~N}$ & 8355 & 77605 & 9.29 & 5816 & 34420 & 5.92 \\
\hline & $40 \mathrm{~N}$ & 5797 & 198983 & 34.33 & 5240 & 21900 & 4.18 \\
\hline & $50 \mathrm{~N}$ & 7959 & 73161 & 9.19 & 6153 & 36435 & 5.92 \\
\hline & $65 \mathrm{~N}$ & 6408 & 87198 & 13.61 & 6145 & 24755 & 4.03 \\
\hline & $5 P$ & 10782 & 75495 & 7.00 & 7361 & 49975 & 6.79 \\
\hline & $10 P$ & 11914 & 86120 & 7.23 & 6817 & 55300 & 8.11 \\
\hline & $20 P$ & 11934 & 86066 & 7.21 & 6801 & 56390 & 8.29 \\
\hline & $30 P$ & 14643 & 83739 & 5.72 & 7766 & 82440 & 10.62 \\
\hline
\end{tabular}

measurements. Figure 6 presents graphs showing the variation of hydration, compressibility, ultrasound velocity, and density in the different materials used in this study. The hydration values of the humates (e.g. KHA, KRHA30N, KRHA40N, KRHA50N, KRHA5P, and KRHA10P) were found to lie relatively high, i.e. between 0.45 and 0.95 grams of water per gram of humate (Figure 6), similar in magnitude to those found for hyaluronan, which is considered to be the most hydrated polysaccharide (Davies et al. 1982; Průšová et al. 2010). This was probably a consequence the high porosity of the humic aggregates (Drastík et al. 2013; Kučerík et al. 2012): the water trapped in their interior contributed to the measured hydration value.

\section{Biological activity}

It was found that the differences between the samples were statistically highly significant (ANOVA $p$-value < 0.001). The results are shown in Figure 7 (boxplot for root growth increment) and Figure 8 (boxplot for root division), and are further summarized in Table 4. Treatments with AtonikPro, AtonikPro + KRHA10N, and AtonikPro + KRHA30P led to significantly lower root growth increments than those of the control group (all with $p$-values $<0.001)$. These treatments also presented decreasing effects on root growth compared to the remaining 11 samples ( $p$-values $<0.001$ ). Plants grown in an AtonikPro solution showed substantially shorter and less divided roots, but their main roots and lateral roots were significantly thicker and presented the highest mass increments. This may have been caused by the nitrophenolate nature of AtonikPro, which is designed to increase the yield of crop plants (Hejnák 2010). In contrast, KRHA50N, KRHA20P, and KRHA30P yielded significantly larger root growth increments compared to the Control ( $p$-values $0.011,0.043$ and 0.011 respectively). Differences among these three samples were comparable (statistically not significant). The differences between the remaining samples
(KRHA10N, KRHA20N, KRHA30N, KRHA40N, KRHA65N, KRHA5P, KRHA10P) and the control group were found not to be statistically significant, despite the fact that the means of sample root growth increments were larger compared to the Control. This may be due to the relatively small number of observations per sample (10), which reduced the reliability of the tests.

The root divisions for the 15 samples were statistically compared in the same way and the differences among the samples were again found to be highly significant. The treatments KHA, KRHA30N, KRHA50N, KRHA65N, and KRHA30P lead to significantly larger root divisions ( $p$-values $0.017,<0.001,<0.001,<0.006$ and $<0.001$ respectively) compared to the control group. Furthermore, the results for KRHA30P were only borderline non-significant ( $p$-value 0.051), and could also be included in the previous group. Finally, the same considerations regarding the test results applied here. The results for KHA and other treatments (except for AtonikPro and Control) did not differ significantly, even though the sample means and medians varied. The highest mass increment was observed in the plants grown in the mixture of $40 \mathrm{mg} \cdot \mathrm{L}^{-1} \mathrm{KRHA} 10 \mathrm{~N}$ and 0.04 vol\% of AtonikPro (sample 13).

The treatment of lignite had an effect on the starch and proteins content of the maize roots. Slightly higher starch contents were found in plants grown in AtonikPro, KHA, KRHA10N and KRHA65N solutions, while the use of AtonikPro, KRHA5P and KRHA10P led to increased protein content (see Table 3 for details).

All of the tested humates exhibited some degree of biological activity with regard to stimulating the growth of maize plants. Materials in both lower and higher molecular weight ranges (e.g. KRHA50N and KRHA30P, respectively) gave statistically significant positive results. Works by Canellas et al. (2002) or Zandonadi et al. (2007) have shown that chemical composition, rather than molecular weight distribution, is the prime factor in 

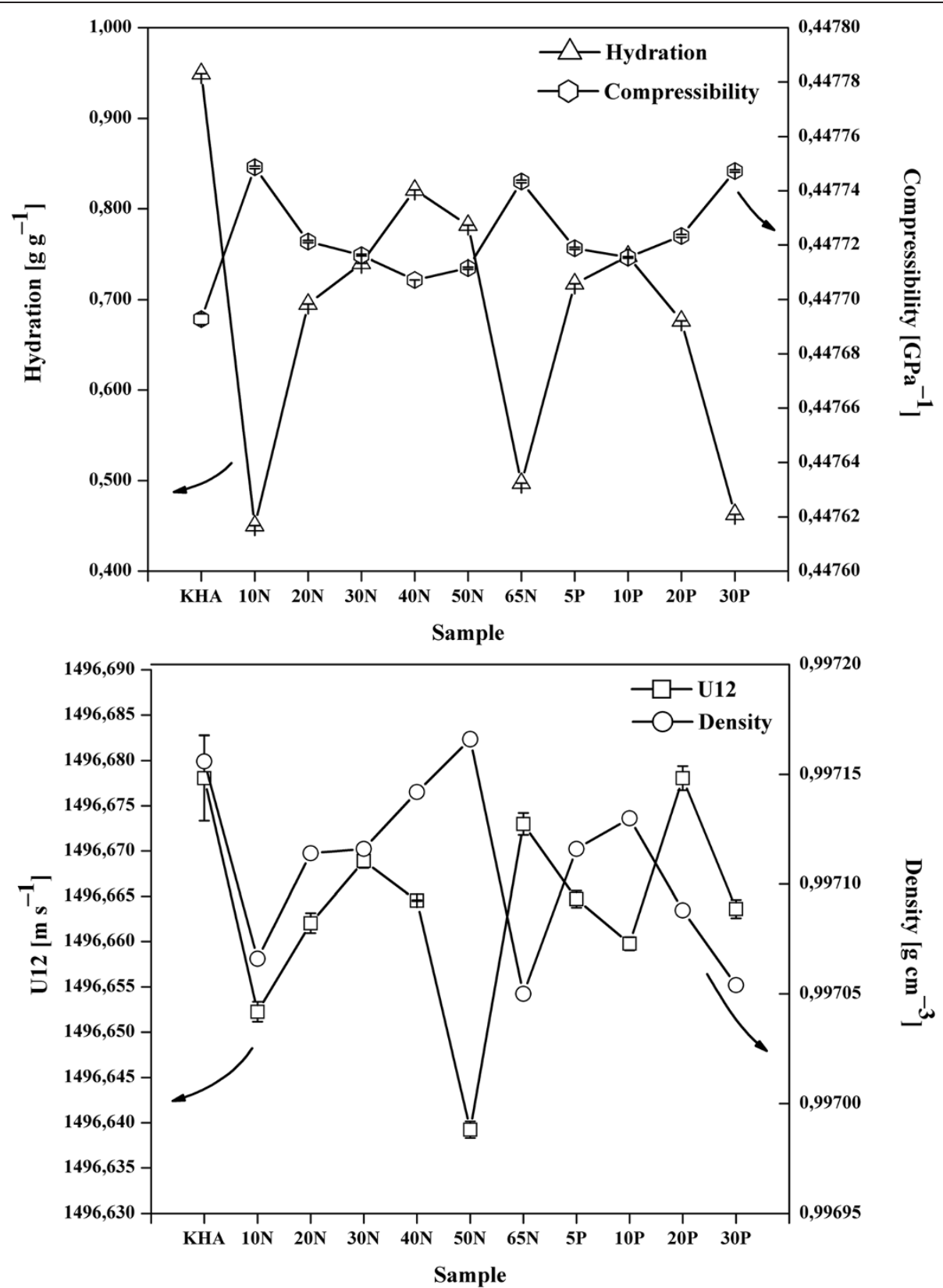

Figure 6 Up: hydration (left axis, triangles) and compressibility (right axis, hexagons) chart; down: ultrasound velocity (U12) (left axis, squares) and density (right axis, circles) chart.

growth stimulation by humates. Most of the regenerated humates generally produced higher root growth (Figure 7) and higher root division (Figure 8), than native humate (KHA) extracted from the parental lignite, it should be noted, however, that neither root growth, nor root division showed enhancements that were statistically significant in all ten regenerated materials, as compared to native KHA. This is in line with the prediction by Vlčková et al. (2009) that oxidation of parental lignite leads to higher biological activity of the resulting humate product. Although the details of the oxidative mechanism are not known yet, it may be suggested that the introduction of additional carboxyl, hydroxyl, amino, and nitro groups play a role. As for root division, higher median values (relative to KHA) were observed for KRHA30N, KRHA50N and KRHA30P.

Table 4 shows that humates regenerated from lignite with nitric acid had positive effects on the starch content of the plants, while selected hydrogen peroxide regenerated humates showed increases in protein content. AtonikPro gave positive results in both cases, presumably because of its nitrophenolate nature (Hejnák 2010). 


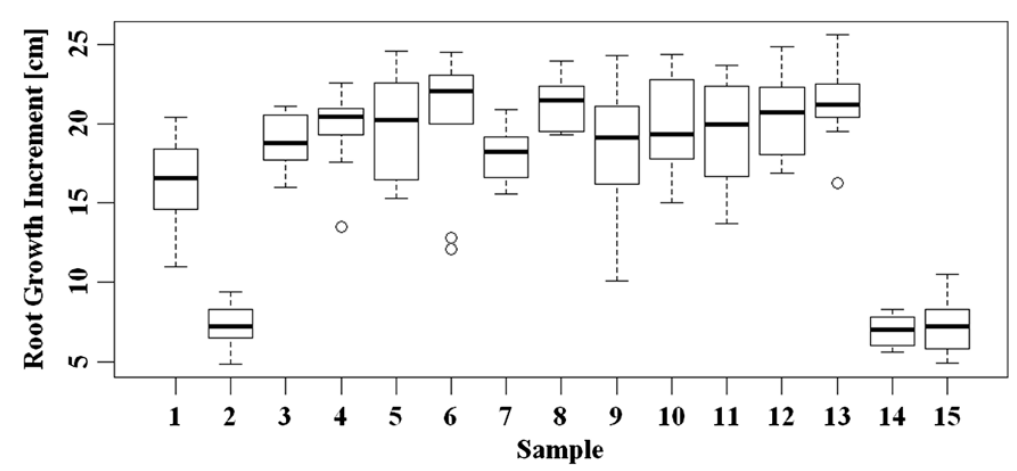

Figure 7 Biological activity - root growth increment boxplot. 1 - Control, 2 - AtonikPro, 3 - KHA, 4 - KHA10N, 5 - KHA20N, 6 - KHA30N, 7 KHA40N, 8 - KHA50N, 9 - KHA65N, 10 - KHA5P, 11 - KHA10P, 12 - KHA20P, 13 - KHA30P, 14 - KHA10N + AtonikPro, 15 - KHA30P + AtonikPro.

\section{Principal component analysis and correlations}

Principal component analysis (PCA) is useful in the identification of patterns that highlight similarities and differences in data sets, especially in cases where the number of results in various measurement categories exceeds the number of samples (Meloun and Militký 2002; Smith 2002). In this work, PCA was applied to RHA and KRHA data generated by FTIR, elemental analysis, and TGA. The results were gathered in a scatter plot (Figure 9), which accounted for $81 \%$ of the variability and recognized 5 groups of samples. The first group comprised RHA10N, RHA10P, RHA5P and RHA20P, having a PC1 loading profile (data not shown) with positive values for the 1st onset TGA peak and IR absorption at 2930, 1520-1550, 1459, and $1422 \mathrm{~cm}^{-1}$. Their thermooxidative degradation started at a relatively high temperatures, and they had a high amide, $\mathrm{C}-\mathrm{O},-\mathrm{OH}$, aromatic $\mathrm{C}=\mathrm{C}$, and aliphatic content. Conversely, RHA65N, RHA20N, RHA30N and RHA50N were positioned along negative part of PC1 and were separated due to their low content of amide, aromatic $\mathrm{C}=\mathrm{C}, \mathrm{C}-\mathrm{O}, \mathrm{O}-\mathrm{H}$ and aliphatic functional groups. At the same time, their values of $\mathrm{N}$,
$(\mathrm{N}+\mathrm{O}) / \mathrm{C}$, and $\mathrm{O} / \mathrm{C}$ were high. An extremely high amount of $\mathrm{N}$ and low amounts of aliphatic, aromatic $\mathrm{C}=\mathrm{C}$ and amide functionalities caused RHA40N to be separated with a very negative $\mathrm{PC}$ score. The positive $\mathrm{PC} 2$ score involving only RHA30P indicated a significant contribution of $\mathrm{H}$ and $\mathrm{H} / \mathrm{C}$ and pointed at low aromaticity. HA, lying along the negative $\mathrm{PC} 2$ axis, varied mainly due to its high char point of $650^{\circ} \mathrm{C}$.

PCA of KRHA samples (data not shown) did not show significant variability in the data, with the first two PC values accounting for only $58 \%$ of data variability. The only significant differences were noted for KRHA40N, KRHA50N, and KRHA30P. The KRHA40N sample had the highest $M_{w}$ and PDI (280 nm) values, while KRHA30P and KRHA50N showed more significant growth increments and root division.

The correlation coefficients shown in Table 4 confirmed that in terms of aliphatic, aromatic and amidic groups' content, the FTIR results correlated well with the results for $\mathrm{C}, \mathrm{H}, \mathrm{O}$ and $\mathrm{N}$ content obtained from elemental analysis. The information from thermogravimetry, giving a negative correlation between $\mathrm{O} / \mathrm{N}$ content and

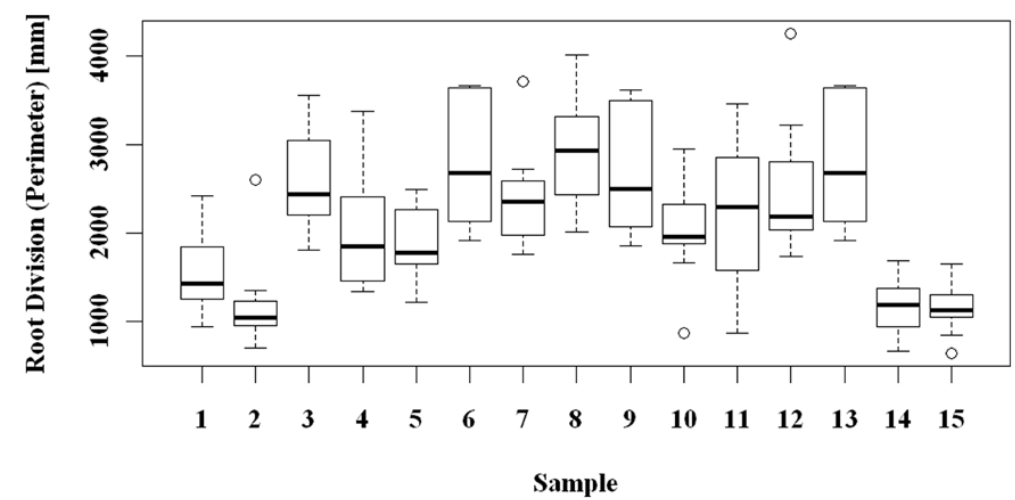

Figure 8 Biological activity - root division (K[BW] - the root fractal measure) boxplot. 1 - Control, 2 - AtonikPro, 3 - KHA, 4 - KHA10N, 5 - KHA20N, 6 - KHA30N, 7 - KHA40N, 8 - KHA50N, 9 - KHA65N, 10 - KHA5P, $11-$ KHA10P, 12 - KHA20P, $13-$ KHA30P, $14-$ KHA10N + AtonikPro, $15-$ KHA30P + AtonikPro. 
Table 4 Biological activity results of humic samples and AtonikPro (Root growth increment, plant mass increment and root division (Perimeter); averages with respective standard deviations

\begin{tabular}{|c|c|c|c|c|c|c|c|c|}
\hline & Sample & Number & Concentration & $\begin{array}{c}\text { Root growth } \\
\text { increment } \\
(2 \times 5 \text { roots }) \\
{[\mathrm{cm}]}\end{array}$ & $\begin{array}{c}\text { Mass increment } \\
(2 \times 30 \text { plants }) \\
{[\mathrm{g}]}\end{array}$ & $\begin{array}{c}\text { K[BW] - root } \\
\text { division } \\
\text { (Perimeter) } \\
(2 \times 5 \text { roots }) \\
\text { [mm] }\end{array}$ & $\begin{array}{c}\text { Starch content } \\
\text { (30 plants } \\
\text { dry mass) } \\
\text { [wt } \%]\end{array}$ & $\begin{array}{c}\text { Protein } \\
\text { content } \\
\text { (30 plants } \\
\text { dry mass) } \\
\text { [wt } \%]\end{array}$ \\
\hline \multirow{15}{*}{ KRHA samples } & Control & 1 & - & $16 \pm 3$ & $27 \pm 0.01$ & $1524 \pm 5$ & 32 & 11 \\
\hline & AtonikPro & 2 & 0.04 vol\% & $7 \pm 1$ & $29 \pm 6$ & $1180 \pm 6$ & 35 & 12 \\
\hline & $\mathrm{KHA}$ & 3 & $40 \mathrm{mg} \mathrm{L}^{-1}$ & $19 \pm 2$ & $30 \pm 6$ & $2573 \pm 6$ & 34 & 11 \\
\hline & $10 N$ & 4 & $40 \mathrm{mg} \mathrm{L}^{-1}$ & $20 \pm 3$ & $29 \pm 0.4$ & $2158 \pm 8$ & 34 & 12 \\
\hline & $20 N$ & 5 & $40 \mathrm{mg} \mathrm{L}^{-1}$ & $20 \pm 3$ & $28 \pm 5$ & $1881 \pm 4$ & 32 & 12 \\
\hline & $30 \mathrm{~N}$ & 6 & $40 \mathrm{mg} \mathrm{L}^{-1}$ & $20 \pm 4$ & $25 \pm 2$ & $2792 \pm 6$ & 32 & 12 \\
\hline & $40 \mathrm{~N}$ & 7 & $40 \mathrm{mg} \mathrm{L}^{-1}$ & $18 \pm 2$ & $26 \pm 0.3$ & $2405 \pm 6$ & 29 & 11 \\
\hline & $50 \mathrm{~N}$ & 8 & $40 \mathrm{mg} \mathrm{L}^{-1}$ & $21 \pm 2$ & $26 \pm 2$ & $2944 \pm 6$ & 32 & 11 \\
\hline & $65 N$ & 9 & $40 \mathrm{mg} \mathrm{L}^{-1}$ & $19 \pm 4$ & $29 \pm 9$ & $2663 \pm 7$ & 34 & 12 \\
\hline & $5 P$ & 10 & $40 \mathrm{mg} \mathrm{L}^{-1}$ & $20 \pm 3$ & $31 \pm 3$ & $2064 \pm 6$ & 33 & 13 \\
\hline & $10 P$ & 11 & $40 \mathrm{mg} \mathrm{L}^{-1}$ & $19 \pm 4$ & $27 \pm 0.5$ & $2253 \pm 9$ & 33 & 13 \\
\hline & $20 P$ & 12 & $40 \mathrm{mg} \mathrm{L}^{-1}$ & $21 \pm 3$ & $30 \pm 3$ & $2477 \pm 8$ & 32 & 12 \\
\hline & $30 P$ & 13 & $40 \mathrm{mg} \mathrm{L}^{-1}$ & $21 \pm 2$ & $31 \pm 5$ & $2792 \pm 7$ & 31 & 11 \\
\hline & $\begin{array}{c}\text { KRHA10N + } \\
\text { AtonikPro }\end{array}$ & 14 & 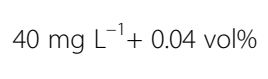 & $7 \pm 1$ & $38 \pm 7$ & $1181 \pm 3$ & 32 & 12 \\
\hline & $\begin{array}{c}\text { KRHA30P + } \\
\text { AtonikPro }\end{array}$ & 15 & $40 \mathrm{mg} \mathrm{L}^{-1}+0.04$ vol\% & $7 \pm 2$ & $32 \pm 2$ & $1144 \pm 3$ & 32 & 11 \\
\hline
\end{tabular}

1st TGA onset temperature, also confirmed that humic acid regeneration reduced the thermal stability of the materials (Gonet and Cieslewicz 1998). Generally, the more $\mathrm{H}$ was present in the humic sample, the lower the amount of ash produced in the thermogravimetric analysis became. Interestingly, the average aggregate particle size (AAPS) of the humates measured by DLS appeared to have no correlation with the molecular weights assessed by DAD and RID in the HPSEC separations. Likewise, no significant correlations of density and ultrasonic velocity with other parameters were observed. As for the HPSEC results, the $M_{\mathrm{N}}$ values obtained by means of the DAD detector (at $280 \mathrm{~nm}$ ) were in a good agreement with those obtained by RID $(r=0.844, p<0.05)$. Further, there was no correlation between $M_{\mathrm{N}}$ and $M_{\mathrm{W}}$ values obtained by DAD, while the correlation of both obtained by RID was significant and positive $(r=0.893$, $\mathrm{p}<0.05)$. This can be ascribed to the fact that the different

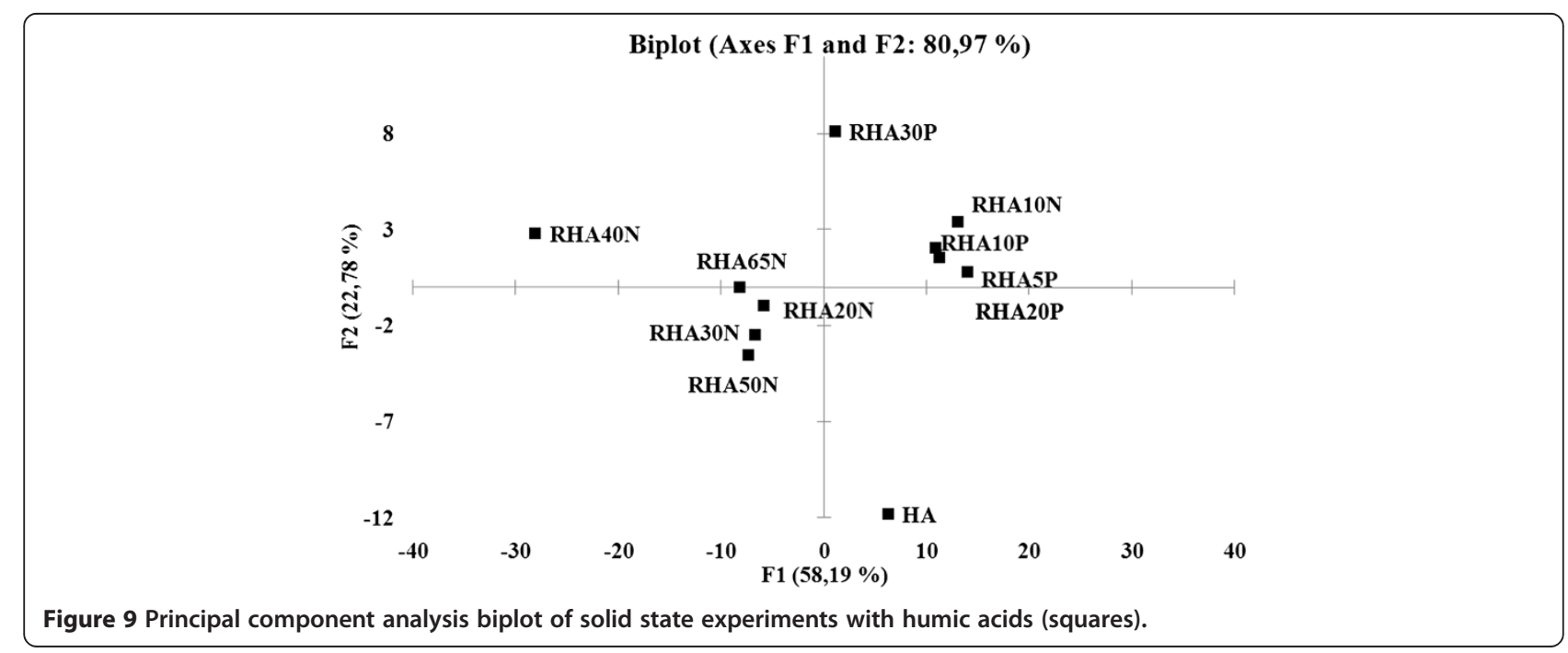


Table 5 Pearson's correlation coefficients of chemical composition with humates' biological activity

\begin{tabular}{|c|c|c|c|c|c|c|c|c|c|c|}
\hline & \multicolumn{7}{|c|}{ Elemental analysis [at\%] } & \multicolumn{3}{|c|}{ FTIR relative peak intensity ratios } \\
\hline & $\mathrm{C}$ & $\mathrm{H}$ & $\mathbf{N}$ & 0 & $\mathrm{H} / \mathrm{C}$ & $\mathrm{N} / \mathrm{C}$ & $\mathrm{O} / \mathrm{C}$ & Aliph./Arom. & Arom./O- groups & Arom./Amid. \\
\hline K[BW] Root division & -0.267 & -0.186 & 0.270 & 0.397 & 0.025 & 0.276 & 0.442 & 0.050 & -0.120 & 0.421 \\
\hline Growth increment & -0.114 & 0.381 & -0.285 & -0.282 & 0.310 & -0.281 & -0.212 & 0.527 & 0.240 & -0.197 \\
\hline Mass increment & 0.475 & 0.290 & -0.696 & -0.528 & -0.024 & -0.686 & -0.645 & 0.350 & 0.291 & -0.631 \\
\hline Sugar content & 0.391 & 0.044 & -0.399 & -0.247 & -0.150 & -0.389 & -0.359 & 0.364 & 0.064 & -0.323 \\
\hline Protein content & 0.181 & 0.214 & -0.183 & -0.398 & 0.040 & -0.180 & -0.398 & 0.168 & 0.248 & -0.377 \\
\hline
\end{tabular}

detectors were sensitive to different moieties. It should be noted that the results of KRHA40N (mainly the DAD HPSEC $M_{\mathrm{W}}$ result) deviated strongly. No explanation is forthcoming for this circumstance, and it should probably be set aside as an artifact.

Inspection of the biological activities revealed that there was no correlation between root division and AAPS or root growth and AAPS. This indicates that these biological parameters were not affected by the aggregate size of the humates dissolved in the growth solution. The molecular weights, in particular $M_{\mathrm{N}}$ obtained with the DAD, did show a moderate correlation with root growth $(r=0.617$, $p<0.05$ ), while $M_{\mathrm{N}}$ values obtained with the RID were similarly correlated with plant mass $(r=0.772, p<0.05)$. Positive correlations were also found for $M_{\mathrm{W}}$ obtained with the RID $(r=0.627, p<0.05)$. The DAD results showed no correlation with mass increment $\left(M_{\mathrm{N}}\right)$ for the entire set of 30 plants, while slightly negative borderline nonsignificant trend $(r=-0.598, p<0.1, p=0.052)$ was found for $M_{\mathrm{W}}$. Positive correlations for molecular weight with root growth increment and plants mass increment were in line with previous findings (Canellas et al. 2010; Nardi et al. 2002). It also appeared that humates containing light absorbing groups induced root growth in Zea mays, with a correlation of $r=0.694, p<0.05$.

As for the relations between biological properties, root division did not correlate with root growth (Tables 4 and 5). Likewise, no positive correlations between the $\mathrm{O}$ and $\mathrm{N}$ content, or the aliphatic and amidic FTIR peak intensity ratios, with root division and root growth was found. Unexpectedly, we found the negative relationship between nitrogen content of the dissolved humates and the biological activity in terms of plants mass increment ( $r=-0.600$ to $-0.700, p$ 's $<0.05$. The correlations between particular molecular weights fractions, as detected by DAD at $280 \mathrm{~nm}$, (Figure 5) and biological characteristics were assessed as well. The high (>100 kDa) and low molecular weight fractions showed no correlation or negative trend with the biological activity (e.g. $r=-0.654$, $p<0.05$ for the root growth increment with the $0-15 \mathrm{kDa}$ fraction). With respect to biological activity, the middle weight fractions of the humates $(50-100 \mathrm{kDa})$ generally produced slightly positive correlations. Similar results were obtained for the nutritional properties of the plants (sugar and protein content). The various correlation values are summarized in Table 6.

These results are in agreement with the findings by Vlčková et al. (2009) and the results of Canellas et al. (2010). Our findings do not agree with Nardi's presumption (Nardi et al. 2002), that the greatest biological activity of humates lies with molecular weight fractions up to $3.5 \mathrm{kDa}$. Our work, however, supports later reports that showed the importance of higher molar weight humates (Canellas et al. 2010; Vlčková et al. 2009; Zandonadi et al. 2007).

\section{Conclusions}

Lignite, in particular the South-Moravian lignite, represents a unique source of humic substances, but its exploitation as a raw material for environmental and agricultural scenarios is still limited. As demonstrated in this and earlier work, regeneration presents a way to increase the recovery of humic substances from lignite, and also allows for the tuning of their properties. The cost-benefit analysis was beyond the scope of this paper; however, the regeneration agents may be preferably recycled into the commercial fertilizer production. This may open a pathway to superior results with the use of

Table 6 Pearson's correlation coefficients of molecular weight distribution fractions (detected by DAD at $280 \mathrm{~nm}$ ) with humates' biological activity

\begin{tabular}{|c|c|c|c|c|c|c|}
\hline & $>100 \mathrm{~kg} \cdot \mathrm{mol}^{-1}$ & $70-100 \mathrm{~kg} \cdot \mathrm{mol}^{-1}$ & $50-70 \mathrm{~kg} \cdot \mathrm{mol}^{-1}$ & $30-50 \mathrm{~kg} \cdot \mathrm{mol}^{-1}$ & $15-30 \mathrm{~kg} \cdot \mathrm{mol}^{-1}$ & $0-15 \mathrm{~kg} \cdot \mathrm{mol}^{-1}$ \\
\hline K[BW] Root division & -0.036 & 0.137 & -0.200 & -0.221 & -0.118 & 0.100 \\
\hline Growth increment & -0.514 & 0.614 & 0.538 & 0.311 & -0.199 & -0.654 \\
\hline Mass increment & -0.371 & 0.420 & 0.502 & 0.206 & -0.195 & -0.491 \\
\hline Sugar content & -0.752 & -0.173 & 0.422 & 0.713 & 0.628 & -0.203 \\
\hline Protein content & -0.279 & -0.082 & 0.271 & 0.353 & 0.230 & -0.145 \\
\hline
\end{tabular}


these materials in agricultural applications. However, full control of these properties and biological activity still remains a challenge.

\section{Competing interests}

The authors declare that they have no competing interests.

\section{Authors' contributions}

JD suggested the broadening of methods of lignite regeneration and biological activity testing, performed most of the experiments, evaluated the data and drafted the manuscript. DŠ contributed with data evaluation from the point of view of Principal component analysis and provided the part of text and figures in this field. $\breve{H}$ contributed with data evaluation from the point of view of statistical tests and collaborated with JD on the statistical evaluation in the R Language and Environment for Statistical Computing and provided the part of the text and figures in this field. OZ contributed with data evaluation from the point of view of image and fractal analysis and taught JD the performing of image analysis in the HarFA software. RvW advised JD during JD's internship in his laboratory, mainly in the field of Dynamic light scattering experiments and further thoroughly rewrote the manuscript. TG analyzed the plants on the protein and sugar content performed the experiments, analyzed these data and provided this part of the text. JK was the main inventor and manager of this work, suggested many of the experiments, checked the data analysis as well as checked, improved and partially wrote the manuscript. All authors read and approved the manuscript.

\section{Acknowledgements}

The Ministry of Education, Youth and Sports of the Czech Republic is acknowledged for funding of this research in terms of the MSM0021630501 research project, as well as for the support of the first author's internship at the University of Idaho in terms of FreeMovers grant. Dr. Noel E. Palmer (University of Idaho, U.S.A.) and Dr. Karolína Benešová (Research Institute of Brewing and Malting, Czech Republic) are acknowledged for helpful discussions. Authors thank the companies Lignit Ltd. Mikulčice/UVR Mnišek pod Brdy, Inc., Czech Republic (raw lignite), ArystaLifeScience Czech Republic (AtonikPro) and Oseva Bzenec Ltd., Czech Republic (CEKLAD 235 corn) for providing their samples for free.

This study was also supported by the CEP Project LO1211 "Materials Research Centre at FCH BUT - Sustainability and Development" from Ministry of Education, Youth and Sports of the Czech Republic.

\section{Author details}

${ }^{1}$ Faculty of Chemistry, Institute of Physical and Applied Chemistry and Materials Research Centre, Brno University of Technology, Purkyňova 464/118, CZ-612 00 Brno, Czech Republic. ${ }^{2}$ Contipro Pharma, Dolní Dobrouč 401, CZ-561 02 Dolní Dobrouč, Czech Republic. ${ }^{3}$ Faculty of Mathematics and Physics, Department of Probability and Mathematical Statistics, Charles University in Prague, Sokolovská 83, CZ-186 75 Prague 8, Czech Republic. ${ }^{4}$ College of Science, Department of Chemistry, University of Idaho, 804 South Rayburn Street, Renfrew Hall Rm 116, PO Box 442343, Moscow 83844-2343 ID, USA. ${ }^{5}$ Faculty of Agronomy, Department of Food Technology, Mendel University in Brno, Zemědělská 1, CZ-613 00 Brno, Czech Republic. 'Institute of Environmental Sciences, Soil and Environmental Chemistry, University of Koblenz-Landau, Fortstrasse 7, D-76829 Landau, Germany.

\section{Received: 7 October 2013 Accepted: 10 February 2014} Published: 21 March 2014

\section{References}

Aguirre E, Leménager D, Bacaicoa E, Fuentes M, Baigiorri R, Zamarreño AM, García-Mina JM (2009) The root aplication of a purified leonardite humic acid modifies the transcriptional regulation of the main physiological root responses to Fe deficiency in Fe-sufficient cucumber plants. Plant Physiol and Biochem 47:215-223

Antošová B, Novák J, Kozler J, Kubíček J, Kimmerová I (2008) Methodic For Testing Biological Activities of Humic Substances On Higher Plants. In: Barroso MI (ed) Reactive and Functional Polymers Research Advances. NovaScience Publishers, New York, pp 191-203

Berkowitz N (1985) The Chemistry of Coal, 1st edn. Elsevier, Amsterdam
Bottomley WB (1917) Some effects of organic growth-promotion substances (auximones) on the growth of Lemma minor in mineral cultural solutions. Proc R Soc Lond B Biol Sci 89:481-505

Brownell JR, Nordstrom G, Marihart J, Jorgensen G (1987) Crop responses from two new leonardite extracts. Sci Total Environ 62:421-499

Canellas LP, Olivares FL, Okorokova-Façanha AL, Façanha AR (2002) Humic acids isolation from earthworm compost enhance root elongation, lateral root emergence, and plasma membrane $\mathrm{H}^{+}$-ATPase activity in maize roots. Plant Physiol 130:1951-1957

Canellas LP, Teixeira Junior LRL, Dobbss LB, Silva CA, Medici LO, Zandonadi DB, Façanha AR (2008) Humic acids cross interactions with root and organic acids. Ann Appl Biol 153:157-166

Canellas LP, Piccolo A, Dobbss LB, Spaccini R, Olivares FL, Zandonadi DB, Façanha AR (2010) Chemical composition and bioactivity properties of size-fractions separated from a vermicompost humic acid. Chemosphere 78:457-466

Conte P, Spaccini R, Šmejkalová D, Nebbioso A, Piccolo A (2007) Spectroscopic and conformational properties of size-fractions separated from a lignite humic acid. Chemosphere 69:1032-1039

Čtvrtničková A, Drastík M, David J, Kučerík J (2011) Surface and solution behavior of surfactants produced from lignite humic acids. Fresen Environ Bull 20:1764-1771

Davies A, Gormally J, Wyn-Jones E, Wedlock DJ, Phillips GO (1982) A study of hydration of sodium hyluronate from compressibility and high precision densitometric measurements. Int J Biol Macromol 4:436-438

Dean RB, Dixon WJ (1951) Simplified statistics for small numbers of observations. Anal Chem 23:636-638

Drastík M, Novák F, Kučerík J (2013) Origin of heat-induced structural changes in dissolved organic matter. Chemosphere 90:789-795

Evdokimov E, von Wandruszka R (1998) Decontamination of DDT-polluted soil by soil washing/cloud point extraction. Anal Lett 31:2289-2298

Eyheraguibel B, Silvestre J, Morard P (2008) Effects of humic substances from organic waste enhancement on the growth and mineral nutrition of maize. Bioresource Technol 99:4202-4212

Fava F, Berselli S, Conte P, Piccolo A, Marchetti L (2004) Effects of humic substances and soya lecithin on the aerobic bioremediation of a soil historically contaminated by polycyclic aromatic hydrocarbons (PAHs). Biotechnol Bioeng 88:214-223

Gonet SS, Cieslewicz J (1998) Differential thermal analysis of sedimentary humic acids in light of their origin. Environ Int 24:629-636

Hejnák V (2010) Vliv růstových regulátorů na fotosyntézu a vodní režim cukrovky prì vodním stresu. Listy cukrovarnické a řepařské 121:27-30

International Humic Substances Society (2013) Elemental Compositions of IHSS Samples. http://www.humicsubstances.org/elements.html. Accessed 10 July 2013

Kennedy JF, Taylor DW, Knill CJ (1995) The effects of busan preservative on apparent starch purity using the EC ewers method. Starch-Starke 47:213-215

Kučerík J, Pekař M, Klučáková M (2003) South-Moravian lignite - potential source of humic substances. Petroleum and Coal 45:58-62

Kučerík J, Cihlár Z, Vlčková Z, Drastík M (2008a) Regenerated humic acids obtained by the Air oxidation of south Moravian lignite. Part. 1. Production and characterization. Petroleum and Coal 50:49-55

Kučerík J, Čechlovská H, Bursáková P, Pekar̆ M (2008b) Lignite humic acid aggregates studied by High Resolution Ultrasonic Spectroscopy Thermodynamical stability and molecular feature. J Therm Anal Calorim 96:637-643

Kučerík J, Bursáková P, Prǔšová A, Grebíková L, Schaumann GE (2012) Hydration of humic and fulvic acids studied by DSC. J Therm Anal Calorim 110:451-459

Laker MC, Dekker J, Cronje IJ (1993) Soil Conditioning. U.S. Patent, p 5248327

McClements J (2001) Analysis of Proteins. http://people.umass.edu/ mcclemen/ 581Proteins.html. Accessed 10 July 2013

Meloun M, Militký J (2002) Kompendium Statistického Zpracování Dat, 1st edn. Academia, Praha

Mora V, Bacaicoa E, Zamarreño AM, Aguirre E, Garnica M, Fuentes M, García-Mina JM (2010) Action of humic acid on promotion of cucumber shoot growth involves nitrate-related changes associated with the root-to-shoot distribution of cytokinins, polyamines and mineral nutrients. J Plant Physiol 167:633-642

Mori S, Barth HG (1999) Size Exclusion Chromatography, 1st edn. Springer-Verlag, Heidelberg

Nardi S, Pizzeghello D, Gessa C, Ferrarese L, Trainotti L, Casadoro G (2000a) A low molecular weight humic fraction on nitrate uptake and protein synthesis in maize seedlings. Soil Biol Biochem 32:415-419 
Nardi S, Concheri G, Pizzighello D, Sturaro A, Rella R, Parvoli G (2000b) Soil organic matter mobilization by root exudates. Chemosphere 41:653-658

Nardi S, Pizzeghello D, Muscolo A, Vianello A (2002) Physiological effects of humic substances on higher plants. Soil Biol Biochem 34:1527-1536

Palmer NE, von Wandruszka R (2001) Dynamic light scattering measurements of particle size development in aqueous humic materials. Fresen J Anal Chem 371:951-954

Piccolo A, Nardi S, Concheri G (1992) Structural characteristics of humic substances as related to nitrate uptake and growth regulation in plant systems. Soil Biol Biochem 24:373-380

Plante AF, Fernández JM, Leifeld J (2009) Application of thermal analysis techniques in soil science. Geoderma 153:1-10

Průšová A, Šmejkalová D, Chytil M, Velebný V, Kučerík J (2010) An alternative DSC approach to study hydration of hyaluronan. Carbohyd Polym 82:498-503

R Development Core Team (2012) R: A Language and Environment for Statistical Computing. R Foundation for Statistical Computing, Vienna, Austria, ISBN 3-900051-07-0, URL http://www.R-project.org/

Rausa R, Girardi E, Calemna V (1994) Humic Acids from Coal. Production, Characterization and Utilization. In: Senesi N, Miano TM (eds) Humic Substances in the Global Environment and Implication on Human Health. Elsevier, Amsterdam, pp 1225-1244

Sanjay HG, Srivastava KC, Walia DS (1999) "Adsorbent". U.S. Patent, p 5906960

Senesi N, Loffredo E (2001) Soil Humic Substances. In: Hofrichter M, Steinbüchel A (eds) Biopolymers: Biology, Chemistry, Biotechnology, Applications - Vol.1: Lignin, Humic substances and Coal. Wiley-VCH, Weinheim, pp 249-299

Šerá B, Novák F (2011) The effect of humic substances on germination and early growth of Lamb's Quarters (Chenopodium album agg.). Biologia 66:470-476

Smith LI (2002) A tutorial on Principal Component Analysis. http://www.ce.yildiz. edu.tr/personal/songul/file/1097/principal_components.pdf. Accessed 10 July 2013

Spaccini R, Piccolo A, Conte P, Haberhauer G, Gerzabek MH (2002) Increased soil organic carbon sequestration through hydrophobic protection by humic substances. Soil Biol Biochem 34:1839-1851

Stehličková L, Šváb M, Wimmerová L, Kozler J (2009) Intensification of phenol biodegradation by humic substances. Int Biodeter Biodegr 63:923-927

Stevenson FJ (1994) Humus Chemistry: Genesis, Composition, Reactions, 2nd edn. John Wiley \& Sons, New York

Swift RS (1996) Organic Matter Characterization. In: Sparks DL (ed) Methods of Soil Analysis. Part 3. Chemical Methods. ASA-CSSA-SSSA Publisher, Madison, pp 1011-1069

Tománková K, Jeřábková P, Zmeškal O, Veselá M, Haderka J (2006) Use of image analysis to study growth and division of yeast cells. J Imaging Sci Techn $50: 1-8$

Vlčková Z, Grasset L, Antošová B, Pekař M, Kučerík J (2009) Lignite pretreatment and its effect on biostimulative properties of respective lignite humic acids. Soil Biol Biochem 41:1901-1984

von Wandruszka R (2000) Humic acids: Their detergent qualities and potential uses in pollution remediation. Geochem Trans, doi:10.1186/1467-4866-1-10

von Wandruszka R, Schimpf M, Hill M, Engebretson R (1999) Characterization of humic acid size fractions by SEC and MALS. Org Geochem 30:229-235

Wu Y-T, Shyu K-K, Jao C-W, Wang Z-Y, Soong B-W, Wu H-M, Wang P-S (2010) Fractal dimension analysis for quantifying cerebellar morphological change of multiple system atrophy of the cerebellar type (MSAC). Neuroimage 49:539-551

Zandonadi DB, Canellas LP, Façanha AR (2007) Indolacetic and humic acids induce lateral root development through a concerted plasmalemma and tonoplast $\mathrm{H}^{+}$pumps activation. Planta 225:1583-1595

Zmeškal O, Veselý M, Nežádal M, Buchníček M (2001) Fractal analysis of image structures. HarFA - harmonic and fractal image analysis. HarFA E J 1:3-5, http://www.fch.vutbr.cz/lectures/imagesci/download_ejournal/01_O.Zmeskal. pdf. Accessed 10 July 2013

\section{doi:10.1186/2193-1801-3-156}

Cite this article as: David et al:: The physico-chemical properties and biostimulative activities of humic substances regenerated from lignite. SpringerPlus 2014 3:156.

\section{Submit your manuscript to a SpringerOpen ${ }^{\circ}$ journal and benefit from:}

- Convenient online submission

- Rigorous peer review

- Immediate publication on acceptance

- Open access: articles freely available online

- High visibility within the field

- Retaining the copyright to your article

Submit your next manuscript at $\boldsymbol{\wedge}$ springeropen.com 